\title{
Influence of Vegetable Oils on pH Profile during Processing of Semidry Fermented Buffalo Meat Sausage
}

\section{Irfan Khan ${ }^{1}$ and Saghir Ahmad ${ }^{2 *}$}

Department of Post-Harvest Engineering and Technology, Aligarh Muslim University, Aligarh, Uttar Pradesh, 202002, India

\begin{abstract}
The experiments were conducted to deduce the effect of lactic acid fermentation and smoking on the $\mathrm{pH}$ of semidry fermented Buffalo meat sausage incorporated with different vegetable oils viz., Canola oil, Safflower oil and olive oil with levels of $15 \%, 20 \%, 25 \%$ individually. The aim was to replace the buffalo white fat with the different levels of vegetable oils (Canola oil, Safflower oil and olive oil) to make a product healthier for human beings as the taken vegetable oils contain good amount of monounsaturated fatty acids, polyunsaturated fatty acids, tocopherols, phytosterols and polyphenols. As the problems related to overdose of saturated fat become prevalent in the society particularly in urban people viz., cardiovascular diseases (atherosclerosis, arteriosclerosis), type-2 diabetes mellitus, polycystic ovary etc. Three samples with each vegetable oil were prepared by taking $15 \%, 20 \%$ and $25 \%$ substitution level in the laboratory. The fermentation of Buffalo meat sausage was performed with the bacterial strains of Lactobacillus plantarum MTCC 1407 and Lactobacillus brevis MTCC1750 in the batch process at $22^{\circ} \mathrm{C}$ temperature for $48 \mathrm{hrs}$. The Lactobacillus bacteria produced the lactic acid during the growth phase under optimum conditions which basically caused the reduction in the $\mathrm{pH}$ of sausage samples. The $\mathrm{pH}$ values of samples were found to reduce from 6.02 before fermentation to the 5.20 after the $48 \mathrm{hrs}$ of fermentation process. A slight increase in the pH of samples was recorded after smoking. The $\mathrm{pH}$ value of the samples was found to decrease after the drying process which was done for $3-5$ days for $70-80^{\circ} \mathrm{Cs}$.
\end{abstract}

Keywords: Vegetable oils; Fermented; pH profile; Buffalo meat

\section{Introduction}

Sausage is the most common meat product of European countries which actually originated from Mediterranean countries [1]. The people are very much attracted by variety of sausages in the world. Various types of sausages are continuously being consumed since a long by human civilisations as meat is the healthier source of protein and other minerals. Now a day's people have become more health conscious i.e. they do not compromise with the safety of food at any cost. So, it becomes essential to make healthier meat products for the targeted consumers. Since a decade ago, the concept of functional meat product has now been introduced and several institutions are working to make healthier functional meat products. Out of the several methods, one way to add functional characteristics in the meat products is the fermentation of meat with lactic acid bacteria. The fermented sausage on the basis of Moisture-Protein Ratio (MPR) can be categorised as dry fermented sausage and semi dry fermented sausage. The most dominating meat fermentation bacteria are lactic acid bacteria and more specifically are Lactobacillus plantarum, Lactobacillus curvatus and Lactobacillus sakei [2]. The most promising bacteria for meat fermentation are indigenous microorganisms [3]. The most promising feature of lactobacillus bacteria is to produce bacteriocin which acts as antimicrobial peptides and enhance the aspects of food safety. There is a variety of bacteriocin that is produced by several lactic acid bacteria. Enterocin MMZ17 is one of class IIa bacteriocin, isolated from "Gueddid", a traditionally Tunisian fermented meat which is small and heat stable listeria active peptide [4] help to improve safety and shelf life of food products [5]. Lactic acid bacteria develop competitive environment to inhibit pathogenic microorganisms by producing variety of bacteriocin [6-8]. The other way to make safe and healthy meat products is the substitution or reduction of saturated fat with the vegetable oils. The low fat fermented sausages are healthier and suggested to vacuum package which thereby inhibit fat oxidation, prevent case hardening and improve appearance as well [9]. The biogenic amines viz., tyramine, 2-phenylethylamine and histamine that are formed during fermentation affect the sensory quality of fermented sausage [10]. Along with fermentation of meat, smoking methods are also being used to add functional or beneficial attributes in meat products. In this article, the effect of fermentation and smoking on buffalo meat sausage has been discussed along with reduction of animal fat with different vegetable oils viz., canola oils, safflower oil and olive oil (virgin). The people are trying to develop variety of meat products by improving their fatty acid profile [11]. The proportion of unsaturated fatty acids improving by incorporating the meat products with variety of vegetable oils [12-14]. The meat is a good source of proteins which is comparatively more bioavailable than any plant based proteins viz., soya protein. Among all the variety of meat, buffalo meat is most suitable for sausage making as it has better emulsion forming ability. Proteins are the building units of human body as it is composed of different types of amino acids which directly or indirectly play a vital role in human body metabolism. The human beings suffer with the various problems linked with the protein deficiency. So, it is mandatory to take good quality protein in appropriate quantity to compensate the need of body metabolism. There are various sources of protein viz., plant based protein and animal based protein. The animal based proteins are of superior quality. The most important attribute of any nutrient

*Corresponding author: Saghir Ahmad, Department of Post-Harvest Engineering and Technology, Aligarh Muslim University, Aligarh, Uttar Pradesh, 202002, India Tel: +91-9412601092; E-mail: alsaghirqadri@gmail.com

Received July 03, 2018; Accepted September 06, 2018; Published September 10, 2018

Citation: Khan I, Ahmad S (2018) Influence of Vegetable Oils on pH Profile during Processing of Semidry Fermented Buffalo Meat Sausage. J Food Process A Technol 9: 756. doi: 10.4172/2157-7110.1000756

Copyright: ( $2018 \mathrm{Khan}$ I, et al. This is an open-access article distributed under the terms of the Creative Commons Attribution License, which permits unrestricted use, distribution, and reproduction in any medium, provided the original author and source are credited. 
is the bioavailability of nutrient to the human body i.e. the quantity of nutrient is not as effective as the availability of that particular nutrient to the human body. The bioavailability in case of animal protein is higher. So the meat is good choice to get protein for better body growth. The buffalo meat is proved superior to make sausage as it is having good emulsion making properties. But there is a problem of high fat content (saturated fat) associated with processed meat products which have to be substituted to make product healthier. The replacement of animal fat with the vegetable oil in the non-fermented meat product is easier than the same in fermented meat products. The reason behind the saga is when $\mathrm{pH}$ goes down the water starts to dissociate with the muscle cells which breaks the integrity of sausage network. That's why it is a cumbersome task to reduce or replace the animal fat with the vegetable oil in fermented meat sausages. The vegetable oils increase the quality fatty acids in the fermented sausage which would automatically make the product healthier. The fatty acid profile of canola oil, safflower oil and olive oil is as below.

\section{Materials and Methods}

\section{Preparation of starter culture for fermentation}

The lyophilised Bacterial strains of Lactobacillus brevis MTCC1750 and Lactobacillus plantarum MTCC 1407 was procured from Imtech Chandigarh, Punjab (India). Each bacterial strain was grown in its respective broth media under optimum temperature $\left(37^{\circ} \mathrm{C}\right)$ and humidity conditions for 24 to 48 hours inside the B.O.D incubator. After optimum growth the starter cultures were then stored at $4^{\circ} \mathrm{C}$.

\section{Preparation of fermented sausage samples}

The fermented sausage samples ( $1.5 \mathrm{~kg}$ sample size) were prepared by mixing with different components viz., Lean meat, fat (10 to $30 \%$ ), Mix spice (15 gm), salt (33 gm), condiments (40 gm), ice (100 gm), sodium nitrate $(0.30 \mathrm{gm})$ and sodium ascorbate $(0.75 \mathrm{gm})$ along with starter culture of Lactobacillus brevis MTCC1750 and Lactobacillus plantarum MTCC 1407 . The animal fat was substituted by vegetable oils viz., canola oil, safflower oil and olive oil. All the ingredients were then chopped homogenously in bowl chopper for 30 minutes. After completing the mixing process, it then transferred to filling machine to fill in cellulose packaging for further processing. The fermentation was carried out inside B.O.D cum humidity chamber at 20 to $22^{\circ} \mathrm{C}$ for 36 to 48 hours.

\section{Smoking of fermented sausage samples}

The sausage samples were smoked followed by fermentation inside the smoke house under controlled temperature and humidity conditions. The smoke was produced with burning of hard wood that carry a variety of nitrogenous compounds. The temperature of smoke was 70 to $80^{\circ} \mathrm{C}$ and the humidity was 80 to $90 \%$.

\section{Drying of smoked sausage samples}

Drying is an important processing step that enhances the shelf life of fermented sausage. The smoked fermented sausage samples were dehydrated inside the drying chamber for 3 to 5 days to prepare semidry fermented sausage with moisture protein ratio in the range of MPR greater than 2.3:1 but less than 3.7:1 [5]. The moisture loss and water activity vary in the range of 8 to $15 \%$ and $0.90-0.94$ respectively [5]

\section{Physicochemical analysis}

The $\mathrm{pH}$ values of sausage samples at different processing stages were determined by Auto pH Meter of Biogen (Model No. BGS-319, S.R No. 101804) in the Department of Post Harvest Engineering \& Technology of Aligarh Muslim University, Aligarh.

\section{Statistical analysis}

The experimental data were subjected to analysis of variance (Two way ANOVA). All statistical analysis were performed using SPSS Version 10.0 for windows (SPSS Inc., Chicago, IL, USA) as described by field (2005).

\section{Results and Discussion}

\section{Effect on $\mathrm{pH}$ value}

The $\mathrm{pH}$ value is the important physicochemical characteristic to decide the quality and shelf life of semidry fermented buffalo meat sausage developed by incorporated with different levels of vegetable oils. Total ten sausage samples (including one control) had $\mathrm{pH}$ values in the range of 6.02 to 4.46 during fermentation, smoking and drying of sausage samples. The control sample was found to have $\mathrm{pH}$ value in the range of 6.32 to 4.66 .

\section{pH profile of sausage samples with canola oil substitution}

The semidry fermented buffalo meat sausage samples incorporated with canola oil, source of unsaturated fatty acids, have different $\mathrm{pH}$

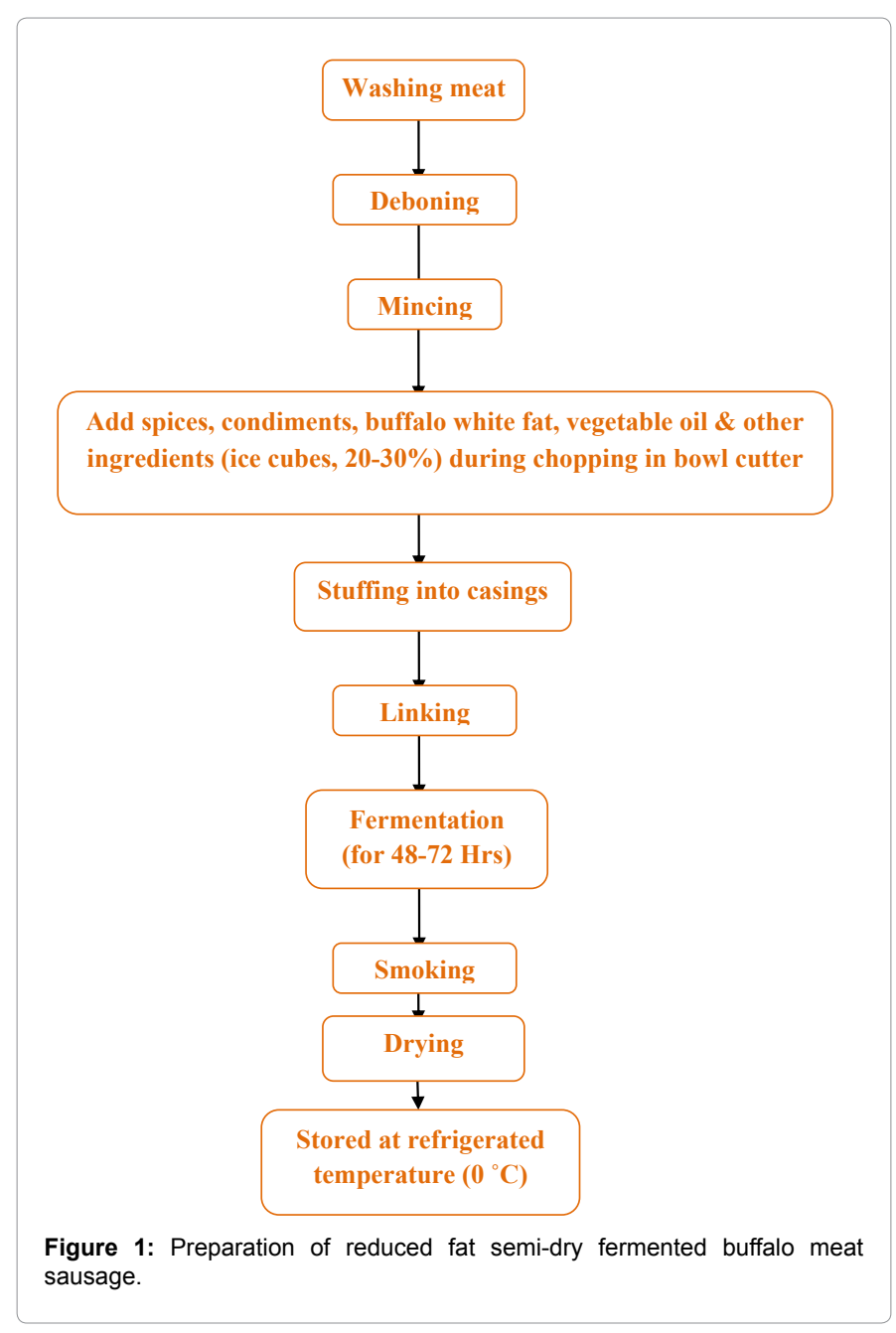


values after fermentation, smoking and drying process. The buffalo white fat used in sausage samples was replaced with 15\%, 20\% and $25 \%$ canola oil. Canola oil has a favourable composition of fatty acids (Figure 1). The Canola oil basically composed of $6 \%$ saturated fatty acids and $94 \%$ unsaturated fatty acids, out of which $63 \%$ oleic acid (a monounsaturated fatty acid), $21 \%$ linoleic acid, $9 \%$ from alpha linolenic acid (a potentially beneficial plant omega-3 fatty acid"), and $7 \%$ saturated fatty acids. The triglyceride fraction of total lipid varies from 94.40-99.10\% and tocopherol content varies from 700 to $1200 \mathrm{ppm}$ [15] which is the potent natural antioxidant. As shown in the Figures 2-4, the $\mathrm{pH}$ of sausage samples were found in the range of 6.02-6.18, 4.685.15, 5.05-5.26 and 4.48-4.63 before fermentation, post-fermentation, post-smoking and post-drying respectively. In each and every level of substitution, the trend of $\mathrm{pH}$ variation is similar i.e. after fermentation; the $\mathrm{pH}$ is decreasing due to lactic acid fermentation and deposition of various organic acids. After fermentation smoking was performed in smoke house with the hard-wood smoke at 70 to $80^{\circ} \mathrm{C}$ temperature with 80 to $90 \%$ humidity. It can clearly be seen from the figures that $\mathrm{pH}$ of sausage samples was increased due to presence of some nitrogenous compounds in the smoke. After smoking, the drying of sausage samples was performed which ultimately drops the $\mathrm{pH}$ of samples due to removal of moisture content which thereby increased the organic acids fraction in the samples.

\section{pH profile of sausage samples with safflower oil substitution}

The semidry fermented buffalo meat sausage samples incorporated with safflower oil, source of unsaturated fatty acids, have different $\mathrm{pH}$ values after fermentation, smoking and drying process. The buffalo white fat used in sausage samples were replaced with 15\%, 20\% and $25 \%$ safflower oil. Safflower (Carthamus tinctorius L.) oil is the good source of polyunsaturated fatty acids viz., tocopherol, and linoleic acid [16]. The safflower oil basically composed of $87.40-90.80 \%$ unsaturated fatty acids and 9.7-10.80 \% saturated fatty acids, out of which $9.5-11.3 \%$ oleic acid (a monounsaturated fatty acid), 77.9 to $79.50 \%$ linoleic acid $[17,18]$. The amount of $\alpha$-tocopherol in safflower oil is 192.05 to 439.64 ppm [19]. As shown in the Figures 5-7, the $\mathrm{pH}$ of sausage samples were found in the range of 6.04 to $6.17,4.67$ to $4.93,4.88-5.18$ and $4.46-4.58$ before fermentation, post-fermentation, post-smoking and post-drying respectively. In each and every level of substitution, the trend of $\mathrm{pH}$ variation is similar i.e. after fermentation; the $\mathrm{pH}$ is decreasing due to lactic acid fermentation and deposition of various organic acids. After fermentation smoking was performed in smoke house with the hardwood smoke at 70 to $80^{\circ} \mathrm{C}$ temperature with 80 to $90 \%$ humidity. It

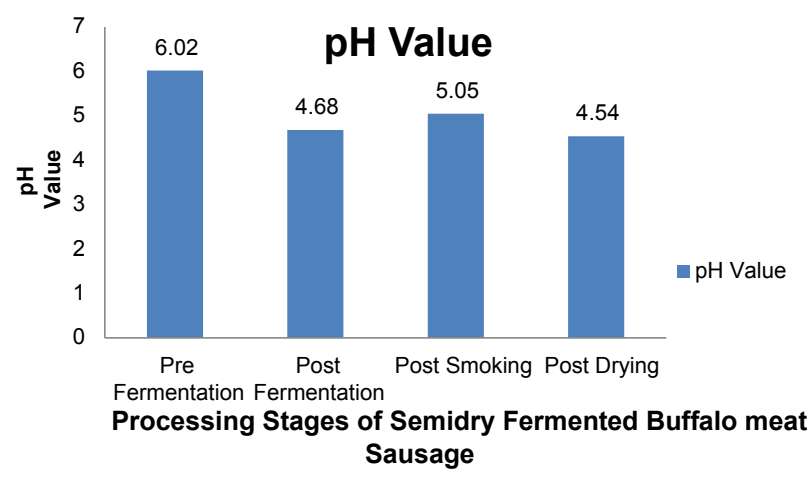

Figure 2: $\mathrm{pH}$ profile of sausage samples with $15 \%$ canola oil substitution.

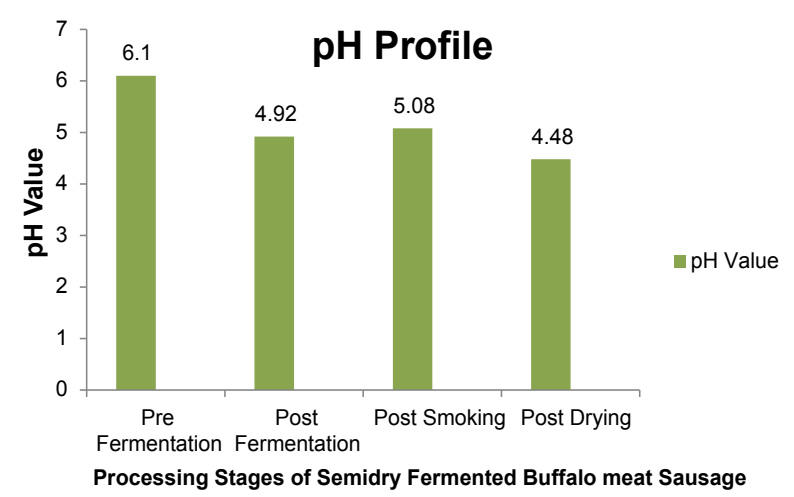

Figure 3: $\mathrm{pH}$ profile of sausage samples with $20 \%$ canola oil substitution.

\section{pH Value}

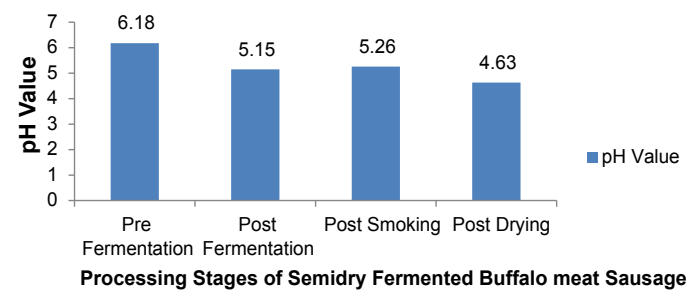

Figure 4: pH profile of sausage samples with $25 \%$ canola oil substitution.

\section{pH Value}

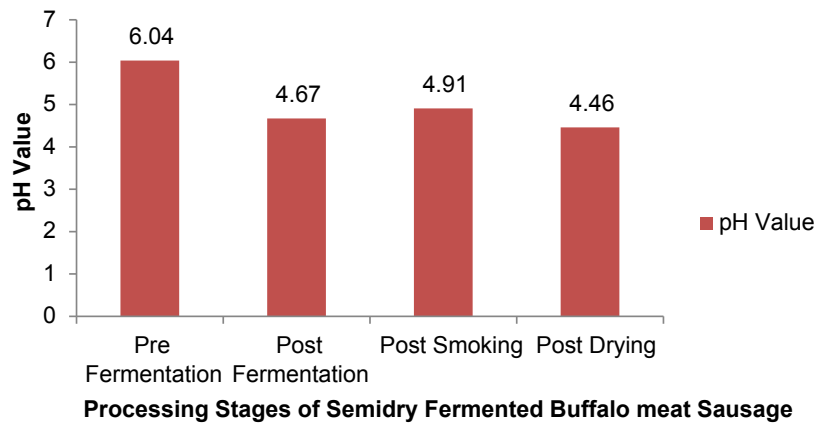

Figure 5: pH profile of sausage samples with $15 \%$ safflower oil substitution.

can clearly be seen from the figures that $\mathrm{pH}$ of sausage samples was increased due to presence of some nitrogenous compounds in the smoke. After smoking, the drying of sausage samples was performed which ultimately drops the $\mathrm{pH}$ of samples due to removal of moisture content which thereby increased the organic acids fraction in the samples.

\section{pH profile of sausage samples with olive oil substitution}

The semidry fermented buffalo meat sausage samples incorporated with olive oil, source of unsaturated fatty acids, have different $\mathrm{pH}$ values after fermentation, smoking and drying process. The buffalo white fat used in sausage samples were replaced with 15\%, 20\% and $25 \%$ olive oil. Olive (Olea europaea L.) oil is the good source of monounsaturated fatty acids particularly oleic acid and it is also rich in 


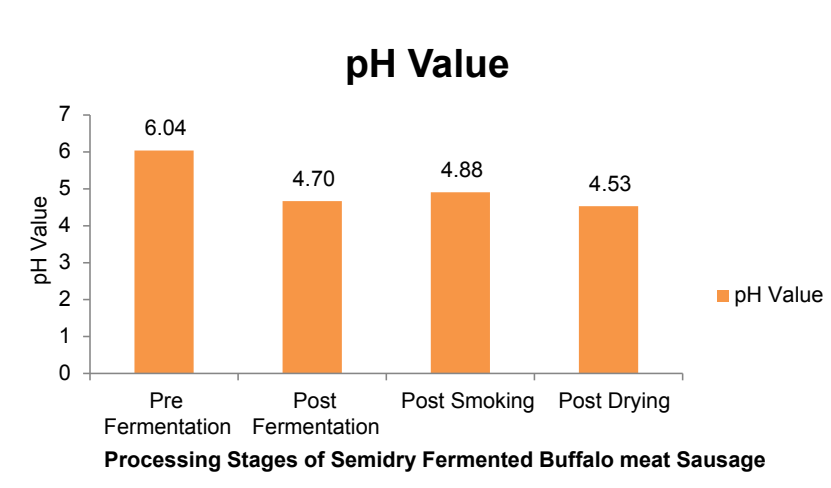

Figure 6: pH profile of sausage samples with $20 \%$ safflower oil substitution.

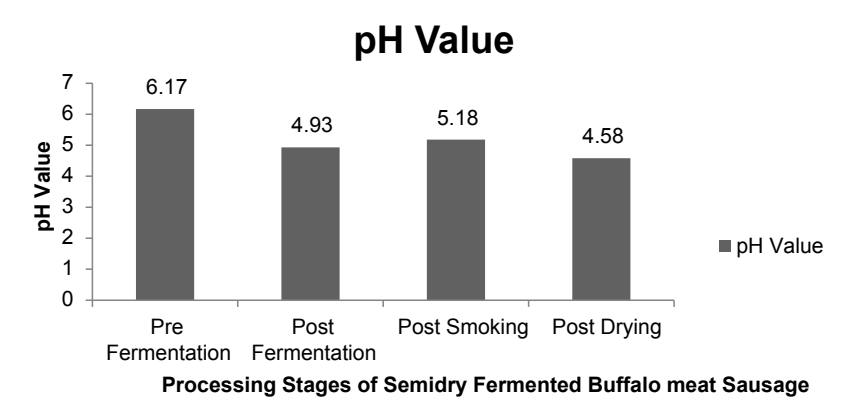

Figure 7: pH profile of sausage samples with $25 \%$ safflower oil substitution.

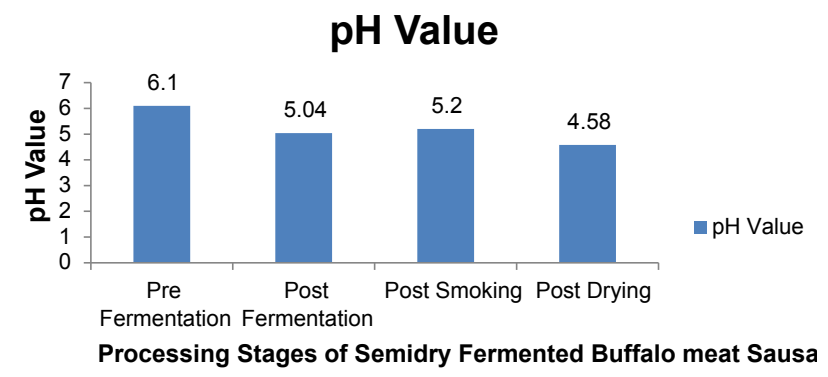

Figure 8: $\mathrm{pH}$ profile of sausage samples with $15 \%$ olive oil substitution.

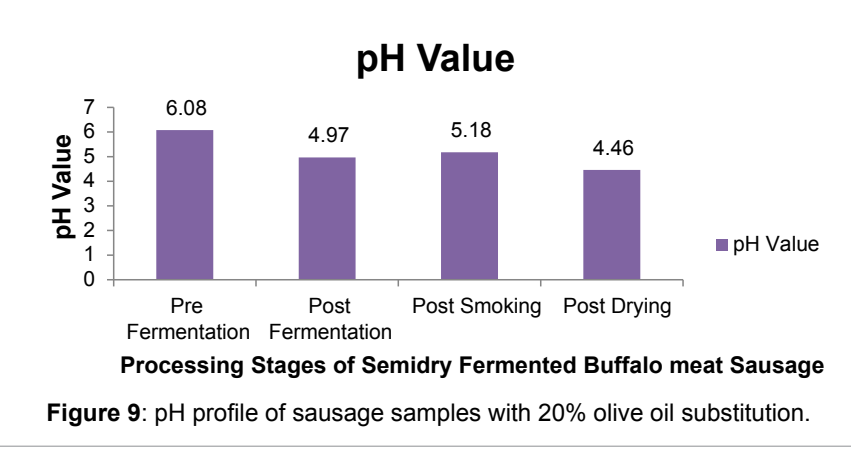

variety of antioxidants viz., tocopherols, polyphenols and phytosterols [20]. The olive oil is rich in oleic acid which is associated with antitumor

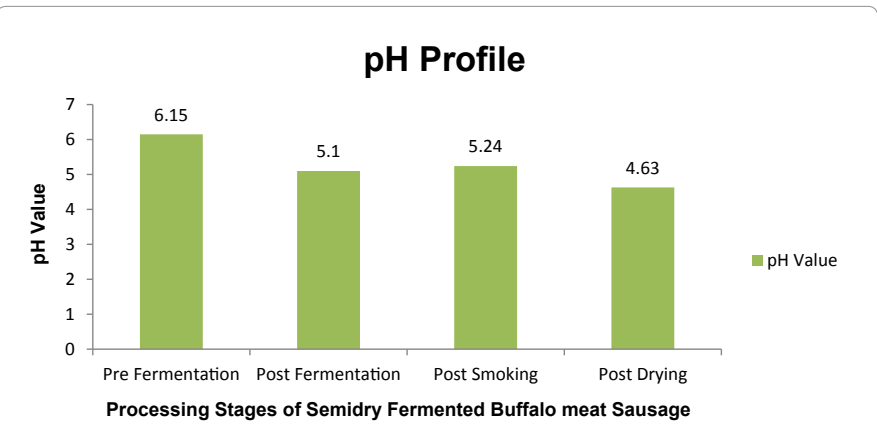

Figure 10: $\mathrm{pH}$ profile of sausage samples with $25 \%$ olive oil substitution.

activity [21]. The oleic acid also helps the human body to fight against oxidative distress. The olive used in the experiment was extra virgin olive oil which was obtained through mechanical cold press method hence no chemical residue present in the olive oil. As depicted in the Figures $8-10$, the $\mathrm{pH}$ of sausage samples were found in the range of 6.08-6.15, 4.97-5.1, 5.18-5.24 and 4.46-4.63 before fermentation, postfermentation, post-smoking and post-drying respectively. In each and every level of substitution, the trend of $\mathrm{pH}$ variation is similar i.e. after fermentation; the $\mathrm{pH}$ is decreasing due to lactic acid fermentation and deposition of various organic acids. After fermentation smoking was performed in smoke house with the hard-wood smoke at 70 to $80^{\circ} \mathrm{C}$ temperature with 80 to $90 \%$ humidity. It can clearly be seen from the figures that $\mathrm{pH}$ of sausage samples was increased due to presence of some nitrogenous compounds in the smoke. After smoking, the drying of sausage samples was performed which ultimately drops the $\mathrm{pH}$ of samples due to removal of moisture content which thereby increased the organic acids fraction in the samples.

\section{Conclusion}

The reduced fat semi-dry fermented buffalo meat sausage prepared by substituting buffalo white fat with vegetable oils to improve the fatty acid profile and nutritional quality of the product. The vegetable oils used are rich in monounsaturated fatty acids, polyunsaturated fatty acids and natural antioxidants viz., oleic acid, linoleic acid, tocopherols, phytosterols etc. The experiments were conducted to observe the effects of vegetable oils on the quality of semidry fermented Buffalo meat sausage samples which ultimately be reflected in terms of $\mathrm{pH}$ profile during preparation of samples. There was no significant influence of different vegetable oils detected individually during fermentation, postfermentation, post-smoking and post-drying. All the samples were found good in terms of $\mathrm{pH}$ profile during processing stages.

\section{Acknowledgements}

The authors thank to the Department of Post-Harvest Engineering \& Technology of Aligarh Muslim University, for providing excellent laboratory facility and cordial environment to complete the experimental work.

\section{References}

1. Comi G, Urso R, lacumin L, Rantsiou K, Cattaneo P, et al. (2005) Characterization of naturally fermented sausages produced in the North East of Italy. Meat Sci 69: 381-392.

2. Hammes WP (1990) Bacterial starter cultures in food production. Food Biotechnol 4: 383-397.

3. Drosinos EH, Mataragas M, Xiraphi N, Moschonas G, Gaitis F, et al. (2005) Characterization of the microbial flora from a traditional Greek fermented sausage. Meat Sci 69: 307-317.

4. Ben Belgacem Z, Ferchichi M, Prévost H, Dousset X, Manai M, et al. (2008) 
Citation: Khan I, Ahmad S (2018) Influence of Vegetable Oils on pH Profile during Processing of Semidry Fermented Buffalo Meat Sausage. J Food Process A Technol 9: 756. doi: 10.4172/2157-7110.1000756

Page 5 of 5

Screening for anti-listerial bacteriocin-producing lactic acid bacteria from "Gueddid" a traditionally Tunisian fermented meat. Meat Sci 78: 513-521.

5. Caplice E, Fitzgerald GF (1999) Food fermentation: Role of microorganisms in food production and preservation. Int J Food Microbiol 50: 131-149.

6. Aguirre M, Collin MD (1993) Lactic acid bacteria and human clinical infection. $J$ Appl Bacteriol 75: 95-107.

7. Smith L, Mann JE, Harris K, Miller MF, Brashears MM (2005) Reduction of E. coli O157:H7 and Salmonella spp. in ground beef using lactic acid bacteria and the impact on sensory properties. J Food Prot 68: 1587-1592.

8. Hoyle AR, Brooks JC, Thompson LD, Palmore W, Stephens TP, et al. (2009) Spoilage and safety characteristics of ground beef treated with lactic acid bacteria. J Food Prot 72: 2278-2283.

9. Liaros NG, Katsanidis E, Bloukas JG (2009) Effect of the ripening time under vacuum and packaging film permeability on processing and quality characteristics of low-fat fermented sausages. Meat Sci 83: 589-598.

10. Getty KK (2005) Dry and Semi-Dry Fermented and Direct Acidified Sausage Validation. National pork board/american meat science association fact sheet.

11. Morgan CA, Noble RC, Cocchi M, McCartney R (1992) Manipulation of the fatty-acids composition of pig meat lipids by dietary means. J Sci Food Agric 58: $357-368$

12. Muguerza E, Gimeno O, Ansorena D, Bloukas JG, Astiasarán I (2001) Effect of replacing pork backfat with pre-emulsiWed olive oil on lipid fraction and sensory quality of "Chorizo de Pamplona" a traditional Spanish fermented sausage. Meat Sci 59: 251- 258
13. Bloukas JG, Paneras ED, Fournitzis GC (1996) Effect of replacing pork backfat with olive oil on processing and quality characteristics of fermented sausages. Meat Sci 45: 133-144.

14. Suzzi G, Gardini F (2003) Biogenic amines in dry fermented sausages: A review. Int J Food Microbiol 88: 41-54.

15. Roman Przybylski. Canola oil: Physical and chemical properties.

16. Han X, Cheng L, Zhang R, Bi J (2009) Extraction of safflower seed oil by supercritical $\mathrm{CO}_{2}$. J Food Eng 92: 370-376.

17. Mihaela P, Josef R, Monica N, Rudolf Z (2013) Perspectives of safflower oil as biodiesel source for South Eastern Europe (comparative study: Safflower, soybean and rapeseed). Fuel 111: 114-119.

18. Ben Moumen A, Mansouri F, Zraibi L, Abid M, Nabloussi A, et al. (2013) Comparative study of four safflower oils (Carthamus tinctorius) varieties grown in eastern of Morocco.

19. Vosoughkia M, Ghavamib M, Gharachorloo M, Sharrifmoghaddasi M, Omidi AH (2011) Lipid composition and oxidative stability of oils in safflower (Carthamus tinctorius L.) seed varieties grown in Iran. Adv Environ Biol 897-903.

20. Wilt TT, MacDonald R, Ishani A (1999) Betasitosterol for the treatment of benign prostatic hyperplasia a systematic review. Br J Urol 83: 976-983.

21. Carrillo C, Cavia MD, Alonso-Torre SR (2012) Antitumor effect of oleic acid, mechanisms of action, a review. Nutr Hosp 27: 1860-1865. 